\title{
Retraction Note to: Inhibition of ZEB1-AS1 confers cisplatin sensitivity in breast cancer by promoting microRNA-129-5p-dependent ZEB1 downregulation
}

\author{
Jin Gao, Yuan Yuan, Lili Zhang, Shaorong Yu, Jianwei Lu, Jifeng Feng and Sainan Hu*
}

\section{Retraction to: Cancer Cell Int (2020) 20:90 https:// doi.org/10.1186/s12935-020-1164-8}

The Editors-in-Chief have retracted this article [1] at the request of the authors because concerns have been raised regarding validity of data.

The authors informed the journal that the bioinformatics analysis and all laboratory contents had been performed by an external company. The outsourced laboratory content includes cell culture, FISH, dual luciferase reporter gene assay, RNA pull down assay, RNA immunoprecipitation (RNA IP) assay, cell grouping and transfection, RT qPCR, western blot analysis, chemosensitivity assay and flow cytometry. This was not made clear in this article. The company has not responded to requests from authors to share raw data. Consequently, the data cannot be verified.

The authors stated that they completed the rest of the work, including clinical patient samples immunohistochemistry analysis, statistical analysis and discussion.

All authors agree to this retraction.

\section{Reference}

1. Gao J, Yuan Y, Zhang L, Yu S, Lu J, Feng J, Hu S. Inhibition of ZEB1-AS1 confers cisplatin sensitivity in breast cancer by promoting microRNA-129-5pdependent ZEB1 downregulation. Cancer Cell In. 2020;20:90. https://doi. org/10.1186/s12935-020-1164-8.

\section{Publisher's Note}

Springer Nature remains neutral with regard to jurisdictional claims in published maps and institutional affiliations.

Published online: 11 January 2021

The original article can be found online at https://doi.org/10.1186/s1293 5-020-1164-8.

*Correspondence: DrSainanHu@163.com

Department of Medical Oncology, Jiangsu Cancer Hospital, Jiangsu

Institute of Cancer Research, The Affiliated Cancer Hospital of Nanjing, Medical University, No. 42 Baiziting, Nanjing 210009, Jiangsu, People's

Republic of China

(c) The Author(s) 2021. This article is licensed under a Creative Commons Attribution 4.0 International License, which permits use, sharing, adaptation, distribution and reproduction in any medium or format, as long as you give appropriate credit to the original author(s) and the source, provide a link to the Creative Commons licence, and indicate if changes were made. The images or other third party material in this article are included in the article's Creative Commons licence, unless indicated otherwise in a credit line to the material. If material is not included in the article's Creative Commons licence and your intended use is not permitted by statutory regulation or exceeds the permitted use, you will need to obtain permission directly from the copyright holder. To view a copy of this licence, visit http://creativeco mmons.org/licenses/by/4.0/. The Creative Commons Public Domain Dedication waiver (http://creativecommons.org/publicdomain/ zero/1.0/) applies to the data made available in this article, unless otherwise stated in a credit line to the data. 